\title{
Investigation of serum and saliva dermcidin levels in patients with recurrent aphthous stomatitis and dermcidin analysis in salivary gland
}

\section{Rekürren aftöz stomatitli hastalarda serum ve tükürükte dermcidin düzeylerinin araştırılması ve tükürük bezinde dermcidin analizi}

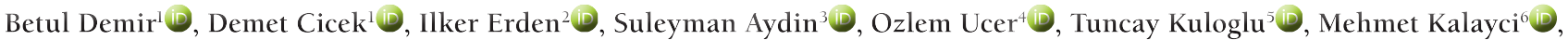
Meltem Yardim ${ }^{7}$, Esma Inan Yuksel ${ }^{1}$ (I)

${ }^{1}$ Dept. of Dermatology, Firat University Hospital, Elazig, Turkey, ${ }^{2}$ Ozel Batman Dunya Hospital, Batman, Turkey, ${ }^{3}$ Dept. of Biochemistry and Clinical Biochemistry, Firat University Hospital, Elazig, Turkey, ${ }^{4}$ Dept. of Pathology, Firat University Hospital, Elazig, Turkey, ${ }^{5}$ Dept. of Histology and Embryology, Firat University Hospital, Elazig, Turkey, ${ }^{6}$ Dept. of Biochemistry Laboratory, Fethi Sekin City Hospital, Elazig, Turkey, ${ }^{7}$ Dept. of Biochemistry Laboratory, Yerkoy Medical Hospital, Yozgat, Turkey
\end{abstract}

\section{Abstract}

Objective Recurrent aphthous stomatitis (RAS) is a common self-limiting oral mucosa disease. In this study, it was aimed to determine the dermcidin level in the serum and saliva of patients with RAS, the presence of dermcidin in the salivary gland and its role in the pathogenesis of RAS.

Methods Thirty-one patients presenting with RAS and 30 control subjects participated in this study. Dermcidin levels in serum and saliva of patients and control group were studied in accordance with the working procedures specified in the catalogs of the human dermcidin ELISA kit. The presence of dermcidin in salivary glands was assessed by immunohistochemical analysis.

Results A statistically significant difference was found when the mean salivary dermcidin levels (105.80 \pm 80.14 $\mathrm{ng} / \mathrm{mL})$ of the RAS patients were compared with the mean salivary dermcidin levels $(456.13 \pm 354.59 \mathrm{ng} / \mathrm{mL}) \mathrm{of}$ the control group $(P=0.000)$. There was no statistically significant difference between the mean serum dermcidin levels $(316.41 \pm 784.55 \mathrm{ng} / \mathrm{mL})$ of the RAS patient and those of $(130.65 \pm 179.75 \mathrm{ng} / \mathrm{mL})$ the control group. Dermcidin immunoreactivity was observed in the parotid gland, submandibular gland and interlobular striated ducts.

Conclusion The findings in this study showed that striated cells in salivary gland synthesized dermcidin. Low levels of dermcidin with antimicrobial properties in saliva were considered as a predisposing factor for RAS.

Key words: dermcidin, recurrent aphthous stomatitis, salivary gland

Corresponding author: Betul Demir, Dept. of Dermatology, Firat University Hospital, Elazig, Turkey,

Phone: +90 507 3403504, E-mail: drbkaraca@yahoo.com

Received: 11 January 2021 Accepted: 20 March 2021

Conflict of Interest: None.

Funding: None

How to cite this article: Demir B, Cicek D, Erden I, et al. Investigation of serum and saliva dermcidin levels in patients with recurrent aphthous stomatitis and dermcidin analysis in salivary gland. Mucosa 2021;4:10-16

(c) (i) (5) This work is licensed under a Creative Commons Attribution-NonCommercial 4.0 International License. 
O̊z

Amaç Rekürren aftöz stomatit (RAS) dudak mukozası, yanak ve dilde, tekrarlayıcı, küçük, ağrılı, eritemli halesi bulunan, nekrotik ülserlerle karakterize, kendi kendini sınırlayabilen, sık görülen bir oral mukoza hastalığıdır. Bu çalışmada RAS'lı hastaların serum ve tükürügünde dermcidin düzeyinin, tükürük bezinde dermcidin varlığının ve RAS patogenezindeki rolünün belirlenmesi amaçlandı.

Yöntem Bu çalışma 31 hasta ve 30 sağlıklı gönüllü ile yapıldı. Hasta ve kontrol grubunun serum ve tükürügündeki dermcidin düzeyleri, insan dermcidin ELISA kitinin kataloglarında belirtilen çalışma prosedürlerine göre çalışıldı. Tükürük bezlerinde dermcidin varlığı immünohistokimyasal analiz ile değerlendirildi.

Bulgular RAS'lı hasta grubunun ortalama tükürük dermcidin düzeyleri (105.80 \pm 80.14), kontrol grubunun ortalama tükürük dermcidin düzeyleri $(456.13 \pm 354.59)$ ile kıyaslandığında istatistiksel anlamlı farklılık tespit edildi $(P=0.000)$. RAS'lı hasta grubunda ortalama serum dermcidin düzeyleri (316.41 \pm 784.55), kontrol grubunun ortalama serum dermcidin düzeyleri (130.65 \pm 179.75) ile kıyaslandığında istatistiksel anlamlı farklılık tespit edilemedi. İmmünohistokimyasal boyamada parotis ve submandibular bezlerde, interlobular kanallarda dermcidin immünreaktivitesi gözlendi.

Sonuç Sonuç olarak bu çalışmada tükürük bezinin striated hücrelerinin dermcidin sentezlediği ortaya kondu. Tükürükte antimikrobial özellikli dermcidin azlığının RAS için predispozan bir faktör olduğu düşünüldü.

Anahtar kelimeler: dermcidin, rekürren aftöz stomatit, tükürük bezi

\section{Introduction}

Recurrent aphthous stomatitis (RAS) is a common self-limiting oral mucosa disease characterized by necrotic ulcers. Many agents, such as genetic factors, food allergies, local trauma, vitamin and element deficiencies, endocrine factors, stress, smoking cessation, chemical substances, viral and bacterial infections have been accused of its etiology. ${ }^{1,2}$ The pathogenesis of RAS has been explained by the activation of proinflammatory cytokines leading to the damage of the oral mucosa under the influence of triggering factors on the basis of genetic susceptibility. ${ }^{2}$ It is known that RAS is associated with microbial agents such as Streptococcus sanguis and inflammatory markers such as TNF- $\alpha{ }^{3}$

Dermcidin was discovered by Schitteck et al. in 2001. The peptide is released from the sweat glands as a precursor protein with a weight of $9.3 \mathrm{kD}$, cleaved by proteolytic enzymes and converted into small peptides with antimicrobial properties. ${ }^{4}$ Some studies have indicated that that the peptides derived from the dermcidin have antibacterial activity against Staphylococcus aureus, Escherichia coli, Enterococcus faecalis $^{4}$, Candida albicans ${ }^{5}$, Staphylococcus epidermidis ${ }^{6}$, Pseudomonas putida, rifampicin- and isoniazid-resistant Mycobacterium tuberculosis ${ }^{7}$ and $P$. acnes. ${ }^{8}$ Also, it was detected that the concentration of dermcidin in the skin of patients with tinea pedis was low, which suggests that dermcidin may be mycostatic activity and may prevent fungal colonization. ${ }^{9}$

This study was planned because of the antimicrobial properties of the dermcidin molecule, and the presence of microbial agents in the etiology of RAS. It is notable that there is no research in the literature that investigating the serum and salivary dermcidin levels of RAS patients. To contribute to the relevant literature, in the present research, we aim to determine the level of dermcidin in the serum and saliva of patients, the presence of dermcidin in the salivary gland, and its role in the pathogenesis of RAS.

\section{Methods}

Thirty-one patients presenting with RAS and 30 control subjects participated in this study. This study was approved by the ethics committee (30.09.2014, no:02) and conducted at a dermatology outpatient clinic. The patient group consisted of participants older than 18 
years old who had clinically recurrent aphthous lesions in the oral mucosa and no other underlying disease. The control group consisted of individuals aged 18 years old or older who applied to the hospital for the annual check-up. Pregnancy, diabetes, hypertension, hyperthyroidism and hypothyroidism, malignancy, alcohol-drug abuse and any systemic drug treatment were considered as an exclusion criteria. Patients and control group were informed about the study and then they gave informed consent.

To obtain saliva, participants were allowed to spit for 1-2 minutes into the sterile urine culture containers after 5 minutes they thoroughly gargled their mouths. A stimulation test was not performed to obtain saliva. 1-2 $\mathrm{mL}$ of saliva was taken into urine culture containers that include the same amount of aprotinin. The samples in the eppendorf tubes were stored at $-80^{\circ} \mathrm{C} .5 \mathrm{~mL}$ fasting blood sample from each participant was taken in the morning. Since dermcidin is a hormone in peptide structure, before receiving blood from the participants, $500 \mathrm{~mL}$ of kallikrein unite aprotinin for $1 \mathrm{~mL}$ was added to the tubes to prevent its disintegration by proteases. After receiving, blood samples were centrifuged, then they were transferred to the eppendorf tubes and stored in the deep freezer $\left(-80^{\circ} \mathrm{C}\right)$ until the analysis.

\section{Immunohistochemical analysis of dermcidin in serum and saliva}

Dermcidin levels in serum and saliva of patients and control group were studied in accordance with the working procedures specified in the catalogs of the human dermcidin ELISA kit Sunred Bioscience (Catalog ID: 201-12-5460 Shanghai, CHINA). Intra-Assay CV value of the reagent was $<10 \%$, while Inter-Assay CV value was $<12 \%$. Plate washes were performed with an automatic washer Bio-Tek ELX50 instrument (BioTek Instruments, USA ) and absorbance measurements were performed by ChroMate, Microplate Reader P4300 instrument (Awareness Technology Instruments, USA). Test results were reported as $\mathrm{ng}$ / $\mathrm{mL}$. The reference range was considered as $1 \mathrm{ng} / \mathrm{mL}$ $300 \mathrm{ng} / \mathrm{mL}$ while sensitivity value was $0.903 \mathrm{ng} / \mathrm{mL}$.
Immunohistochemical analysis of dermcidin in the salivary gland was performed with salivary gland tissue without any pathology (n:10), which was previously excised for any reason and sent to pathological examination. Immunohistochemical staining of the tissues was performed using the method of Hsu et al. ${ }^{10}$ The amount of dermcidin in the tissue was measured by the ELISA method ${ }^{11}$ after the saliva gland was grinded in the phosphate buffer. Anti-DCD/ Dermcidin antibody (aa96-110) produced by LSBio (Life Span BioSciences, Inc.) (Catalog ID/Lot ID: LSC128574/32734) was used for the measurement.

Sections with 5-6 mm in thickness taken from paraffin blocks were transferred into the slides with polylysine. The deparaffinized tissues were passed through graded alcohol series and boiled in the microwave $(750 \mathrm{~W})$ for $7+5$ minutes at $\mathrm{pH}: 6$ in citrate buffer solution for antigen retrieval. The tissues that were left to cool in the room temperature for about 20 minutes after boiling were incubated with hydrogen peroxide block solution for 5 minutes ( Hydrogen Peroxide Block, TA-125-HP, Lab Vision Corporation, USA) to prevent endogenous peroxidase activity after washing for $3 \times 5$ minutes with PBS (Phosphate Buffered Saline, P4417, Sigma-Aldrich, USA). After Ultra V Block solution (TA-125-UB, Lab Vision Corporation, USA) was applied for 5 minutes to the tissues washed with PBS for $3 \times 5$ minutes to prevent floor paint, 1/200 of diluted primary antibody (Anti-DCD/Dermcidin Antibody, aa96-110, Life Span BioSciences, Inc., Seattle, USA) was incubated for $60 \mathrm{~min}$ in a humid environment at room temperature. The tissues were incubated at room temperature for 30 minutes in a humidified environment with a secondary antibody (biotinylated Goat Anti-Polyvalent (anti-mouse/rabbit $\operatorname{IgG~} 80^{\circ} \mathrm{C}$ ), TP-125-BN, Lab Vision Corporation, USA) after washing with PBS for $3 \times 5$ minutes and application of the primer antibody. The tissues were washed with PBS for $3 \times 5$ minutes after the application of secondary antibody, and then, incubated with PBS (Streptavidin Peroxidase, TS-125-HR, Lab Vision Corporation, USA) for 30 minutes at room temperature in humidified atmosphere and finally transferred to the PBS. After 
the solution of 3-amino-9-ethylcarbazole (AEC) Substrate+AEC Chromogen (AEC Substrate, TA-015 and HAS, AEC Chromogen, TA-002-HAC, Lab Vision Corporation, USA) were added to the tissues. The vision signal was taken on the light microscope, the tissues were simultaneously washed with PBS. Mayer's hematoxylin-counterstained tissues were covered with the appropriate closure solution (Large Volume Vision Mount, TA-125-UG, Lab Vision Corporation, USA) after the applications of PBS and distilled water. Preparations were photographed by examining on a Leica DM500 microscope (Leica DFC $29580^{\circ} \mathrm{C}$ ).

\section{Statistical analysis}

SPSS version 22.0 was used for statistical analysis. The values obtained in the study were given as mean \pm SD. Student t-test and Mann-Whitney-U test were applied for inter-group comparisons. $P<0.05$ were considered statistically significant.

\section{Results}

A total of 61 participants consisting of 28 (45.9\%) female and $33(54.1 \%)$ male were included in the present study. A total of 31 patients consisting of 15 (48.4\%) female and 16 (51.6\%) male were enrolled in the patient group, while there were 30 volunteers as 13 (43.3\%) female and 17 (56.7\%) male in the control group. Patients were in the age range between 21-55 years, with a mean age of $34.22 \pm 9.00$ and the age range was between $18-48$ years and mean age was

Table 1. Demographic and laboratory characteristics of the patient and the control group

\begin{tabular}{lccc}
\hline Parameters & RAS & Control & $P$ \\
\hline $\mathbf{n}$ & 31 & 30 & \\
Gender (M/F) & $16 / 15$ & $17 / 13$ & $P>0.05$ \\
Age* (year) $_{\text {Serum Dermcidin (ng/mL) }}$ & $34.22 \pm 9.00$ & $34.80 \pm 8.00$ & $P>0.05$ \\
Saliva Dermcidin (ng/mL) & $105.80 \pm 80.14$ & $456.13 \pm 354.59$ & $P=0.000$ \\
\hline *(Mean \pm SD) & & & \\
RAS, Recurrent aphthous stomatitis & & &
\end{tabular}

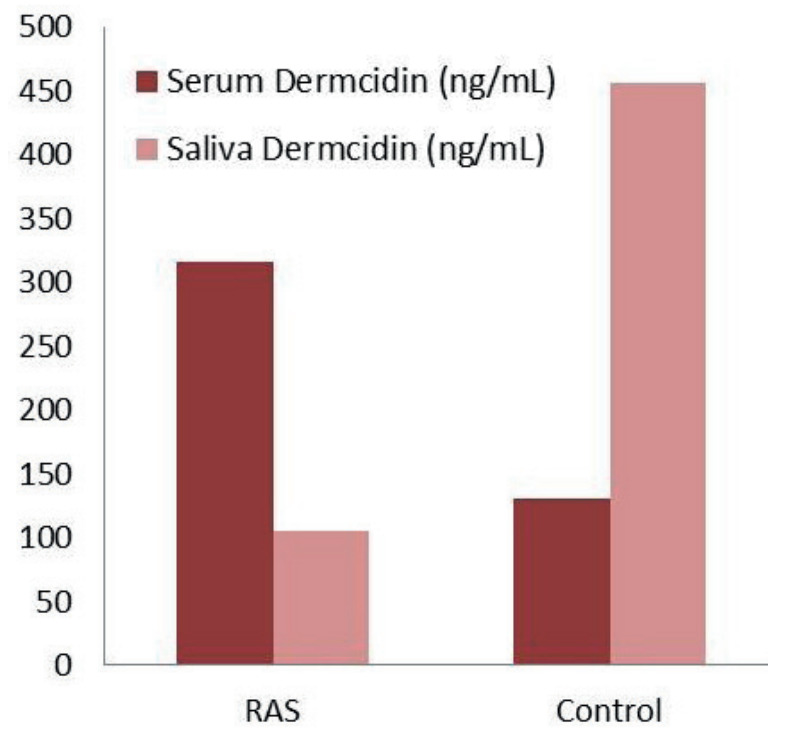

Fig. 1. Serum and saliva dermcidin levels of the patients and control groups
$34.80 \pm 8.00$ in the control group (Table 1 )

A statistically significant difference was found when the mean salivary dermcidin levels $(105.80 \pm 80.14$ $\mathrm{ng} / \mathrm{mL}$ ) of the RAS patients were compared with the mean salivary dermcidin levels $(456.13 \pm 354.59 \mathrm{ng} /$ $\mathrm{mL})$ of the control group $(P=0.000)$. There was no statistically significant difference between the mean serum dermcidin levels $(316.41 \pm 784.55 \mathrm{ng} / \mathrm{mL})$ of the RAS patient and those of $(130.65 \pm 179.75 \mathrm{ng} / \mathrm{mL})$ the control group. (Table 1) (Fig. 1).

Although serum dermcidin levels were higher in women with RAS $(489.59 \pm 1068.63 \mathrm{ng} / \mathrm{mL})$ than men with RAS $(154.05 \pm 327.23 \mathrm{ng} / \mathrm{mL})$, the difference was not statistically significant. Similarly, although the salivary dermcidin levels in patients were higher 
in female patients $(120.77 \pm 112.42 \mathrm{ng} / \mathrm{mL})$ than male patients $(91.77 \pm 24.81 \mathrm{ng} / \mathrm{mL})$, the difference was not statistically significant. Also, for the control group serum and saliva dermcidin levels were higher in females than males but these differences were not statistically significant. In addition, a significant correlation was not found out between serum and salivary dermcidin levels.

Parotid (Fig. 2a) and submandibular glands (Fig. 2b) were used to investigate dermcidin immunoreactivity. Dermcidin immunoreactivity was observed in the parotid gland (Fig. 2c) and submandibular gland (Fig. 2d) and interlobular ducts.

\section{Discussion}

In this study, to our knowledge, dermcidin concentrations in saliva of patients were determined for the first time. Also, in this study, salivary glands contribute to dermcidin levels are investigated. In addition, an immunohistochemical scanning of dermcidin was performed on the salivary glands to detect the source of the dermcidin in the saliva. Our findings showed that there was immunoreactivity of dermcidin in striated portions of submandibular and parotid salivary glands.

Saliva has many functions, including moisturizing,
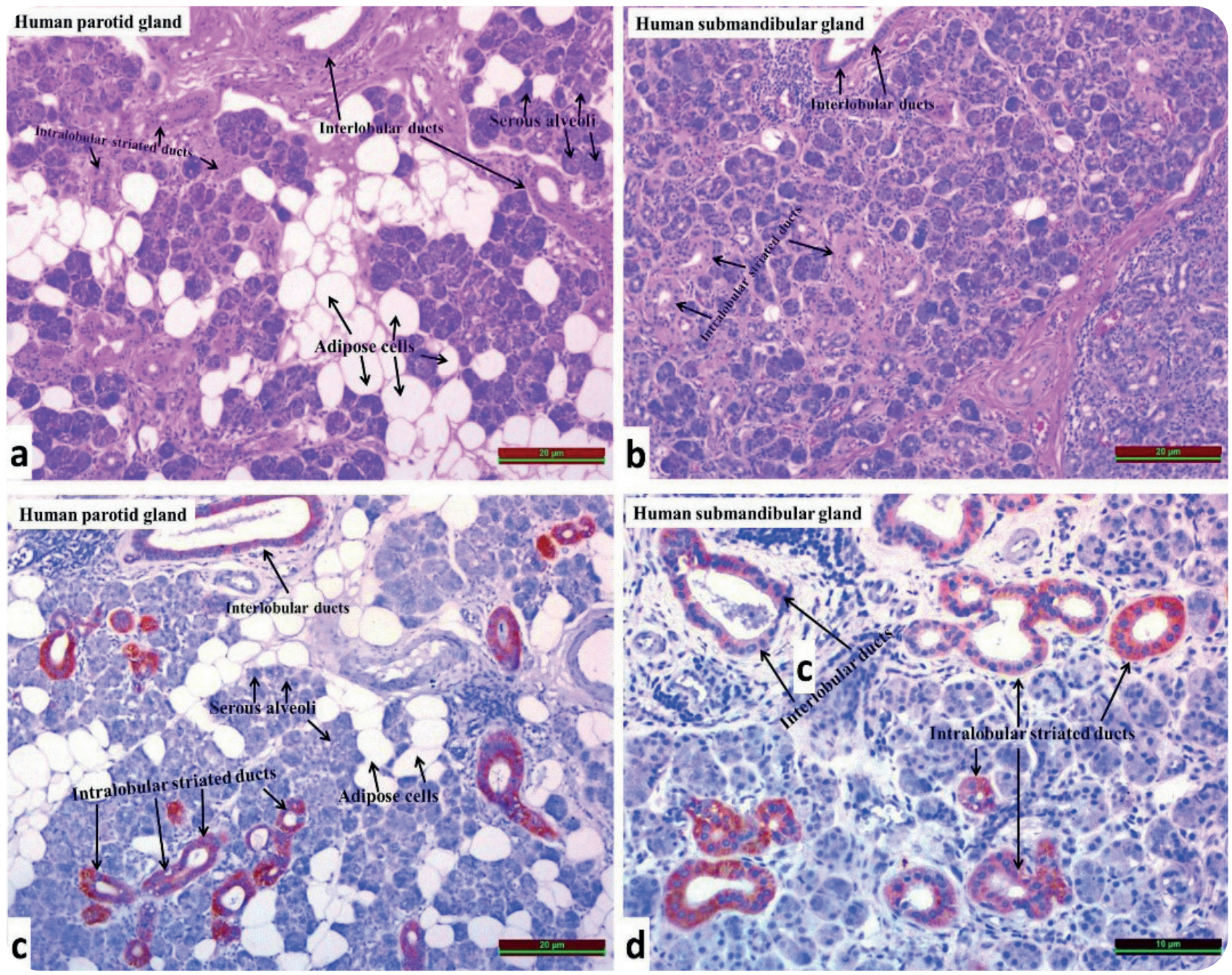

Fig. 2. Parotid (2a.) and submandibular (2b.) glands, dermcidin immunoreactivity in parotid (2c.), and submandibular glands (2d.) and interlobular ducts 
lubrication and cleaning of the oral cavity, helping digestion and talking, contributing to dental health, antimicrobial and immunological properties. ${ }^{12}$ Many salivary proteins and antimicrobial peptides contribute for the defense system of saliva. ${ }^{13}$ Antimicrobial peptides form a natural antibiotic layer on the surface of the oral mucosa as a strong member of the innate immune response and activate the acquired immunity against pathological conditions. ${ }^{14}$ Antimicrobial peptides detected in saliva are $\alpha$ and $\beta$-defensins, histatins, LL-37 and cathelicidin. ${ }^{15}$ Previous proteomic studies have also reported the presence of dermcidin in the saliva; however, it was not detected which cells of the salivary gland synthesize dermcidin. ${ }^{16,17}$ Therefore, to our knowledge, this is the first study that showed which cells of the salivary glands synthesized dermcidin.

In a previous study, peptides deriving from dermcidin could not be detected in body fluids, such as nasal secretion, tears and saliva ${ }^{18}$, while the analysis of dermcidin was performed in cervicovaginal fluid ${ }^{19}$ and tear $^{20}$ in some other studies. It has been thought that dermcidin is not a peptide with a high concentration in body fluids. ${ }^{21}$ In this study, it was shown that the mean dermcidin level of $456 \mathrm{ng} / \mathrm{mL}(0.456 \mu \mathrm{g} / \mathrm{mL})$ in the saliva of healthy controls.

The antimicrobial action mechanism of dermcidin in saliva is unknown. However, relevant studies reported that the peptides derived from dermcidin exhibit antimicrobial effect without permeabilization to microbial membranes. ${ }^{5,22}$ It has been shown that dermcidin may contribute to cutaneous immunity by releasing various cytokines, such as TNF- $\alpha$, interleukin-8 with activating keratinocytes.Dermcidin was unaffected by salt, $\mathrm{pH}$, and inflammatory media. ${ }^{22}$ and was at an excessively stable level. ${ }^{21}$

In this study, salivary dermcidin levels in patients decreased. In the light of this information and results obtained in this research, it was detected that patients were sensitive to microbial agents on the basis of genetic susceptibility and considering the fact that antimicrobial dermcidin was also capable of triggering inflammation. Thus, the findings suggest that low dermcidin levels in the saliva result in a predisposition to infections and contribute to the development of aphthae.

In this study, how the level of antimicrobial dermcidin in saliva changes as well as the relationship between its salivary level, and its serum level were investigated in patients. The dermcidin synthesized from the salivary gland appears to be transferred to both the saliva and the serum. Since salivary dermcidin levels in controls were higher than its serum levels, the findings suggest that the main source of dermcidin in serum was salivary gland and this condition could be contribute to the serum level of dermcidin synthesized in the salivary gland. However, it is notable that that salivary and serum dermcidin levels of the patients were not parallel, and there was not a significant difference between patients and the control group regarding serum dermcidin levels. This finding suggests that salivary dermcidin rather than serum may be a candidate biomarker of the disease in patients.

The findings in this study showed that striated cells in salivary gland synthesized dermcidin. Low levels of dermcidin with antimicrobial properties in saliva were considered as a predisposing factor for RAS. In light of insightful findings, this study sheds light on novel treatment methods.

Acknowledgments: Thanks to the NOVA translation company for language translation.

Ethics committee approval:

Local Ethics Committee approval was obtained (30.09.2014, no:02)

Informed consents: They were obtained.

Peer-review: Externally peer-reviewed.

Authorship contributions:

Conception and design, or analysis and interpretation of data: BD, DC, IE, SA, OU, TK, MK, MY

Drafting the manuscript or revising the content: BD, DC, EIY

Final approval of the version to be published: BD, DC 


\section{References}

1. Belenguer-Guallar I, Jimenez-Soriano Y, Claramunt-Lozano A. Treatment of recurrent aphthous stomatitis. A literature review. J Clin Exp Dent 2014;6:168-74.

2. Slebioda Z, Szponar E, Kowalska A. Etiopathogenesis of recurrent aphthous stomatitis and the role of immunologic aspects: literature review. Arch Immunol Ther Exp (Warsz) 2014;62:205-15.

3. Chavan M, Jain H, Diwan N, Khedkar S, Shete A, Durkar S. Recurrent aphthous stomatitis: a review. J Oral Pathol Med 2012;41:577-83.

4. Schittek B, Hipfel R, Sauer B, et al. Dermcidin: a novel human antibiotic peptide secreted by sweat glands. Nat Immunol 2001;2:1133-7.

5. Mehra T, Koberle M, Braunsdorf C, MailanderSanchez D, Borelli C, Schaller M. Alternative approaches to antifungal therapies. Exp Dermatol 2012;21:778-82.

6. Vuong C, Voyich JM, Fischer ER, et al. Polysaccharide intercellular adhesin (PIA) protects Staphylococcus epidermidis against major components of the human innate immune system. Cell Microbiol 2004;6:269-75.

7. Lai YP, Peng YF, Zuo Y, et al. Functional and structural characterization of recombinant dermcidin-1L, a human antimicrobial peptide. Biochem Biophys Res Commun 2005;328:243-50.

8. Nakano T, Yoshino T, Fujimura T, et al. Reduced expression of dermcidin, a peptide active against propionibacterium acnes, in sweat of patients with acne vulgaris. Acta Derm Venereol 2015;95:783-6.

9. Arai S, Yoshino T, Fujimura T, et al. Mycostatic effect of recombinant dermcidin against Trichophyton rubrum and reduced dermcidin expression in the sweat of tinea pedis patients. J Dermatol 2015;42:70-6.

10. Hsu SM, Raine L, Fanger H. Use of avidin-biotinperoxidase complex $(\mathrm{ABC})$ in immunoperoxidase techniques: a comparison between $\mathrm{ABC}$ and unlabeled antibody (PAP) procedures. J Histochem Cytochem 1981;29:577-80.

11. Aydin S. A short history, principles, and types of ELISA, and our laboratory experience with peptide/protein analyses using ELISA. Peptides 2015;72:4-15.

12. Holmberg KV, Hoffman MP. Anatomy, biogenesis and regeneration of salivary glands. Monogr Oral Sci 2014;24:1-13.

13. Dawes C, Pedersen AM, Villa A, et al. The functions of human saliva: a review sponsored by the World Workshop on Oral Medicine VI. Arch Oral Biol 2015;60:863-74.

14. van't Hof W, Veerman EC, Nieuw Amerongen AV, Ligtenberg AJ. Antimicrobial defense systems in saliva. Monogr Oral Sci 2014;24:40-51.

15. Dale BA, Tao R, Kimball JR, Jurevic RJ. Oral antimicrobial peptides and biological control of caries. BMC Oral Health 2006;6:13.

16. Denny P, Hagen FK, Hardt M, et al. The proteomes of human parotid and submandibular/sublingual gland salivas collected as the ductal secretions. J Proteome Res 2008;7:1994-2006.

17. Preza D, Thiede B, Olsen I, Grinde B. The proteome of the human parotid gland secretion in elderly with and without root caries. Acta Odontol Scand 2009;67:161-9.

18. Rieg S, Seeber S, Steffen H, et al. Generation of multiple stable dermcidin-derived antimicrobial peptides in sweat of different body sites. J Invest Dermatol 2006;126:354-65.

19. Shaw JL, Smith CR, Diamandis EP. Proteomic analysis of human cervico-vaginal fluid. J Proteome Res 2007;6:2859-65.

20. You J, Fitzgerald A, Cozzi PJ, et al. Post-translation modification of proteins in tears. Electrophoresis 2010;31:1853-61.

21. Schittek B. The multiple facets of dermcidin in cell survival and host defense. J Innate Immun 2012;4:349-60.

22. Wiesner J, Vilcinskas A. Antimicrobial peptides: the ancient arm of the human immune system. Virulence 2010;1:440-64. 